\title{
PENTINGNYA PENDIDIKAN KARAKTER TERHADAP PSIKOLOGI PESERTA DIDIK SEKOLAH MENENGAH KEJURUAN
}

\author{
Dian Ekawati Nur ${ }^{1}$, Muhammad Yahya ${ }^{2}$, Hendra Jaya ${ }^{3 *}$ \\ ${ }^{I}$ Program S2 PTK Pascasarjana UNM, ${ }^{2,3}$ Fakultas Teknik Universitas Negeri Makassar \\ E-Mail: dianekawatinur@yahoo.com,muhammad.yahya@unm.ac.id, hendra.jaya@unm.ac.id \\ *Corresponding Author
}

\begin{abstract}
Abstrak
Pendidikan karakter merupakan berbagai usaha yang dilakukan oleh berbagai personil sekolah terutama SMK, bahkan yang dilakukan bersama - sama dengan orang tua dan anggota masyarakat untuk membantu anak - anak dan remaja agar menjadi atau memiliki sifat peduli, berpendirian, dan bertanggung jawab. Metode penelitian kajian pustaka atau studi kepustakaan yaitu berisi teori - teori yang relevan dengan masalah - masalah penelitian. Menyikapi pentingnya pendidikan karakter, maka sangat diperlukan pendidikan karakter di sekolah untuk mewujudkan peradaban bangsa dengan memberikan keteladanan dan pembiasaan. Setelah dilakukan pengkajian teori, disimpulkan bahwa pendidikan karakter tentunya sangat penting bagi peserta didik untuk menanamkan nilai-nilai moral di dalam dirinya dan melatihnya untuk melakukan kebiasaan - kebiasaan yang baik. Pendidikan karakter juga berfungsi untuk membangun suatu karakter pesarta didik karena kakater itulah yang akan mendominasi sifat dan bukti diri dari peserta didik tersebut.
\end{abstract}

Kata Kunci: Pendidikan Karakter. Psikologi Pendidikan.

\begin{abstract}
Character education is a variety of efforts undertaken by various school personnel, especially vocational schools, even those carried out jointly with parents and community members to help children and adolescents to become or have a caring, opinionated, and responsible nature. Literature study research method or literature study that contains theories that are relevant to research problems. Responding to the importance of character education, it is very necessary character education in schools to realize the nation's civilization by providing exemplary and habituation. After a theoretical study, it is concluded that character education is certainly very important for students to instill moral values in themselves and train them to do good habits. Character education also serves to build a student character because it is the character who will dominate the nature and self-evidence of the students.
\end{abstract}

Keywords: Character Education. Educational Psychology

\section{PENDAHULUAN}

Menurut Syah

(2010:24)

Psikologi pendidikan merupakan sebuah disiplin psikologi yang khusus mempelajari, meneliti dan membahas seluruh tingkah laku manusia yang terlibat dalam proses pendidikan itu meliputi tingkah laku belajar (oleh siswa), tingkah laku mengajar (oleh guru), dan tingkah laku mengajar-belajar (oleh guru dan siswa yang saling berinteraksi).

Pembangunan pendidikan tidak hanya untuk mengembangkan aspek intelektual saja melainkan watak, moral, 
sosial serta fisik peserta didik. Dengan kata lain pendidikan bertujuan untuk menciptakan generasi yang lebih hebat. Upaya ini dilakukan dalam rangka meningkatkan mutu sumber daya manusia dan mutu pendidikan. Terjadinya degradasi moral pada sebagian remaja telah menjadi tantangan bagi dunia pendidikan sebagaimana yang diungkapkan oleh rita damayanti ( kurniawan dkk. (2010) ), Sekolah menengah kejuruan (SMK) merupakan lembaga pendidikan penghasil lulusan yang diharapkan siap berkompetisi di dunia kerja, maka lulusannya dituntut tidak hanya memiliki hard skill akan tetapi soft skill. Hard skill dapat di bentuk pada diri peserta didik melalui masing - masing bidang keahlian. Soft skill merupakan keterampilan kepribadian yang terbentu karena penanaman nilai kebajikan. Lulusan SMK yang bermoral rendah tidak layak bekerja dimanapun, untuk itu anggapan masyarakat umum bahwa peserta didik SMK memiliki sikap brutal, nakal, susah diatur, suka kroyokan, dan konotasi negatif lainnya harus segera diubah. Pendidikan karakter telah diwacanakan sebagai solusi untuk membentuk kepribadian yang baik pada diri peserta didik. Namun, penerapan pendidikan karakter masih belum dapat dilakukan secara menyeluruh dalam suatu sistem yang terorganisir yang ada di SMK saat ini.

\section{Pendidikan Karakter}

Pendidikan karakter adalah suatu sistem penamaan nilai-nilai karakter yang meliputi komponen pengetahuan, kesadaran atau kemauan, dan tindakan untuk melaksanakan nilai-nilai tersebut, baik terhadap Tuhan Yang Maha Esa, diri sendiri, sesama, lingkungan, maupun kebangsaan. Pengembangan karakter bangsa dapat dilakukan melalui perkembangan karakter individu seseorang.Akan tetapi, karena manusia hidup dalam lingkungan sosial dan budaya tertentu, maka perkembangan karakter individu seseorang hanya dapat dilakukan dalam lingkungan sosial dan budaya yang bersangkutan. Artinya, perkembangan budaya dan karakter dapat dilakukan dalam suatu proses pendidikan yang tidak melepaskan peserta didik dari lingkungan sosial,budaya masyarakat, dan budaya bangsa.Lingkungan sosial dan budaya bangsa adalah Pancasila, jadi pendidikan budaya dan karakter adalah mengembangkan nilai-nilai Pancasila pada diri peseta didik melalui pendidikan hati, otak, dan fisik

\section{Budaya Asing Yang Masuk ke Indonesia}

Budaya asing yang masuk ke Indonesia membawa dampak yang sangat besar dalam kehidupan generasi muda saat ini. Tidak semua budaya asing membawa dampak positif bagi generasi muda saat ini,untuk itu kita sebagai generasi muda harus dapat memilahmilah budaya asing yang masuk ke indonesia. Dalam menyikapi kebudayaan yang masuk kita harus berupaya menanggulanginya agar jati diri kita sebagai anak bangsa tidak rusak. Banyaknya tindak kejahatan yang terjadi saat ini juga tidak lepas dari budaya asing yang masuk, tindak kriminal, narkoba,tawuran, perkosaan, pergaulan bebas terjadi karena generasi muda kita meniru kebudayaan asing yang menurut mereka sudah tidak tabu lagi untuk diikuti. Inilah fenomena yang terjadi pada generasi muda kita saat ini akibat tidak bisa memilah budaya asing yang masuk.

\section{Peran Psikologi}

Peran psikologi terhadap pendidikan karakter mampu menjadi wadah untuk mengenalkan bagaimana pendidikan karakter itu sendiri, lalu mampu membangun sikap dan perilaku yang baik serta menunjukkan pentingnya memiliki karakter yang baik. Psikologi juga dapat mempengaruhi budaya suatu 
bangsa. Kita mungkin juga familiar dengan istilah antropologi. Ini karena sifat psikologi yang terus dikembangkan. Nilai dalam kehidupan bermasyarakat mungkin bisa bergeser dan mengalami perubahan manakala ditemukan hal baru dalam psikologi yang sifatnya bisa lebih diterima dan juga dipandang lebih baik dibandingkan dengan nilai sebelumnya. Hal ini kemudian akan berkembang dan mempengaruhi budaya yang sebelumnya sudah ada.

\section{METODE PENELITIAN}

Metode Penelitian ini merupakan metode penelitian kajian pustaka atau studi kepustakaan yaitu berisi teori teori yang relevan dengan masalah - masalah penelitian.

Jenis penelitian yang digunakan dalam penelitian ini adalah penelitian kepustakaan atau library research, yakni penelitian yang dilakukan melalui mengumpulkan data atau karya tulis ilmiah yang bertujuan dengan obyek penelitian atau pengumpulan data yang bersifat kepustakaan, atau telaah yang dilaksanakan untuk memecahkan suatu masalah yang pada dasarnya tertumpu pada penelaahan kritis dan mendalam terhadap bahan-bahan pustaka yang relevan.

1. Jenis dan Sifat Penelitian

Dilihat dari jenis penelitiannya, adapun jenis penelitian yang digunakan dalam penelitian ini adalah penelitian kepustakaan atau library research, yakni penelitian yang dilakukan melalui mengumpulkan data atau karya tulis ilmiah yang bertujuan dengan obyek penelitian atau pengumpulan data yang bersifat kepustakaan, atau telaah yang dilaksanakan untuk memecahkan suatu masalah yang pada dasarnya tertumpu pada penelaahan kritis dan mendalam terhadap bahan-bahan pustaka yang relevan (Fithri, 2017).

2. Metode Pengumpulan Data Adapun metode pengumpuluan data penelitian ini diambil dari sumber data, Yang dimaksud sumber data dalam penelitian adalah subjek dari mana data dapat diperoleh. Apabila peneliti menggunakan dokumentasi, maka dokumen atau catatanlah yang menjadi sumber data, sedangkan isi catatan subjek penelitian atau variable penelitian.

3. Teknik Analisis Data

Setelah keseluruhan data terkumpul maka langkah selanjutnya penulis menganalisa data tersebut sehingga ditarik suatu kesimpulan. Untuk memperoleh hasil yang benar dan tepat dalam menganalisa data, penulis menggunakan teknik analisis isi.Analisis isi (Content Analysis) Adalah penelitian yang bersifat pembahasan mendalam terhadap isi suatu informasi tertulis atau tercetak di media massa.

\section{HASIL DAN PEMBAHASAN}

Hasil penelitian yang mengungkap pentingnya pendidikan karakter oleh Zamtinah, Untung Kurniawan, Doni Sarosa, Rahmah Tyasari (2011) model pendidikan karakter dibuat dengan pendekatan norma dan kearifan lokal Kota Yogyakarta. Hasil uji kelayakan memperlihatkan bahwa tujuan pendidikan karakter sangat baik untuk digunakan dan dikembangkan. Isi, metode berupa pelaksanaan, metode berupa penjagaan, alat pendidikan berupa tindakan, lingkungan pendidikan karakter, serta peserta didik, baik untuk digunakan dan dikembangkan. Alat pendidikan yang bersifat kebendaan, dan 
rumusan pendidik dinilai cukup baik untuk digunakan dan dikembangkan lebih lanjut.

Menurut Binti Maunah (2015) pembentukan karakter anak dapat dilakukan melalui dua strategi, yaitu internal sekolah dan eksternal sekolah. Kedua, strategi internal sekolah dapat dilakukan melalui empat pilar, yakni kegiatan proses belajar mengajar di kelas, kegiatan keseharian dalam bentuk budaya sekolah (school culture), kegiatan pembiasaan (habituation), kegiatan kokurikuler dan ekstra kurikuler. Ketiga, strategi eksternal dapat dilakukan melalui keluarga dan masyarakat. Keempat, ketika seluruh strategi tersebut dapat dilaksanakan dengan baik, maka karakter anak akan menjadi terbentuk dan kuat.

Nopan Omeri (2015) Pendidikan karakter adalah suatu sistem penamaan nilai-nilai karakter yang meliputi komponen pengetahuan, kesadaran atau kemauan, dan tindakan untuk melaksanakan nilai-nilai tersebut, baik terhadap Tuhan Yang Maha Esa, diri sendiri, sesama,lingkungan, maupun kebangsaan. Pengembangan karakter bangsa dapat dilakukan melalui perkembangan karakter individu seseorang.Akan tetapi, karena manusia hidup dalam lingkungan sosial dan budaya tertentu,maka perkembangan karakter individu seseorang hanya dapat dilakukan dalam lingkungan sosial dan budaya yang bersangkutan. 2.Strategistrategi dalam PerkembanganPendidikan Berkarakter salah satunya adalahStrategi Pendidikan Karakter melalui Multiple Intelligence (Multiple Talent Approach) Strategi inibertujuan untuk mengembangkan seluruh potensi anak didik yang merupakan Pengembangan potensi yang membangun self concept yang menunjang kesehatan mental.

\section{KESIMPULAN}

Berdasarkan hasil pembahasan dapat disimpulkan bahwa pendidikan karakter tentunya sangat penting bagi peserta didik untuk menanamkan nilainilai moral di dalam dirinya dan melatihnya untuk melakukan kebiasaan kebiasaan yang baik. Pendidikan karakter juga berfungsi untuk membangun suatu karakter pesarta didik karena kakater itulah yang akan mendominasi sifat dan bukti diri dari peserta didik tersebut.

\section{DAFTAR PUSTAKA}

Maunah Binti. 2015. Implementasi Pendidikan Karakter Dalam Pembentukan Kepribadian Holistik Siswa. Diterbitkan melalui online. Aceh: IAIN Tulungagung.

Zamtinah, Untung Kurniawan, Doni Sarosa, Rahmah Tyasari (2011). Model Pendidikan Karakter Untuk Sekolah Menengah Kejuruan. Diterbitkan melalui online. FT Universitas Negeri Yogyakarta

Nopan Omeri (2015) Pentingnya
Pendidikan Karakter Dalam Dunia
Pendidikan. Diterbitkan
Online. Selalui
Makmur. SMA Negeri 1 Arga

